\title{
Perspectivas de la metáfora y el símbolo desde la teoría de Paul Ricœur
}

\author{
Perspectives of Metaphor and Symbol \\ Drawn from the Theory of Paul Ricœur
}

\author{
Iram Isaí Evangelista Ávila \\ Universidad Autónoma de Chihuahua \\ Facultad de Filosofía y Letras \\ ievangelista@uach.mx \\ orcid.org/oooo-0oo2-1065-082X
}

Resumen: Este artículo elabora algunas aproximaciones a los conceptos de metáfora y símbolo, desde la teoría que Paul Ricœur plasma en La metáfora viva y algunos otros trabajos como Del texto a la acción y El conflicto de las interpretaciones. Asimismo, para contextualizar ciertos usos, se tomarán algunos apuntes que hace Mauricio Beuchot en sus acercamientos al estudio del símbolo. Símbolo y metáfora nos llevan a refigurar la obra de arte literaria y nos transportan a otro horizonte. La aplicación del ejercicio recaerá en un fragmento de "El prodigioso miligramo" de Juan José Arreola.

Palabras clave: metáfora, símbolo, interpretación, método

Abstract: This paper proposes some approaches to the concepts of metaphor and symbol from Paul Ricœur's discourse in The Rule of Metaphor, and some other essays such as From Text to Action and The Conflict of Interpretations. Likewise, to contextualize certain terms, I will use some of the notes by Mauricio Beuchot as he approaches the concept of symbol. Symbol and metaphor transport us to reconfigure the literary work of art as a whole and take us into another horizon. The application of this exercise will fall in an excerpt of "El prodigioso miligramo" by Juan José Arreola.

Keywords: metaphor, symbol, interpretation, method

Recibido: 18 de mayo de 2019

Aceptado: $\quad$ 10 de septiembre de 2020 
¿Cómo se abordan la metáfora y el símbolo en la teoría de Paul Ricœur? El hermeneuta francés hace suyos estos dos tropos y los disemina en gran parte de su producción teórica. Este trabajo es una aproximación a sus postulados y elabora acercamientos que pueden contribuir a la mejor comprensión de estas figuras dentro del campo teórico literario. Nos centraremos en lo expuesto en el libro La metáfora viva, pero también en publicaciones como El conflicto de las interpretaciones y Del texto a la acción. El camino sugerido por Ricœur para interpretar la metáfora lo expone dentro de La metáfora viva; sin embargo, para la aproximación al símbolo utilizaremos el método Subtilitas de la hermenéutica analógica propuesto por Mauricio Beuchot. El siguiente trabajo es un esfuerzo interdisciplinar que sugiere la teoría ricoeuriana y la analogía como métodos idóneos para la comprensión del texto literario, y, asimismo, busca contribuir con nuestra visión de la metáfora y el símbolo dentro del campo teórico literario.

Como inicio, se aborda el planteamiento de la metáfora, figura literaria que nos proyecta una reconstrucción del sentido de lo referencial.

\section{Metáfora}

La metáfora nace desde los cimientos de una idea que podemos llamar referencial. ¿Por qué desde los cimientos? Porque lo que interesa no es el significado del concepto en sí, o del juicio unívoco; lo que importa es lo que recibimos, evocamos y proyectamos de la nueva construcción. En esta figura literaria extrapolamos la significación referencial a una polisémica. La metáfora es la reconstrucción de un significado, que da pie a crear otro lenguaje, imaginativo e interpretativo: "El lenguaje poético destruye la referencia espontánea del lenguaje ordinario, y, en virtud de la distancia que toma con respecto a la realidad natural (mediante una suspensión de referencia o 'epojé, dicho en términos fenomenológicos), abre nuevas dimensiones de la realidad" (Domingo 2003: párr. 33). La génesis de la metáfora obedece a un plano poiético, esto es, a una recreación de los usos del lenguaje establecidos culturalmente. Nos encontramos ante una concepción artística del objeto. Con esta regeneración de sentido, se significa más a través de lo sensorial, de lo personal, de lo universal. Max Black en Modelos y metáforas, menciona que la metáfora se construye y se proyecta: "lo importante para la eficacia de la metáfora no es que los lugares comunes sean verdaderos, sino que se evoquen presta y espontáneamente" (1966: 50). Black y Ricœur concuerdan en que la 
metáfora se plantea y se construye por medio de la oración: focus y frame, donde el "foco" es una palabra que conlleva una carga de significaciones varias (es polisémica), mientras que el "marco" es el resto de la oración. De esta manera, la palabra metafórica nos entrega un bosque de posibilidades, pero la oración nos otorga la vereda. Ricœur dice:

El hombre es un lobo. El foco - un lobo-opera, no en virtud de su significación lexical ordinaria, sino por el "sistema de lugares comunes asociados", es decir, en virtud de las opiniones y prejuicios en los que el locutor de una comunidad lingüística se halla comprometido, por el solo hecho de hablar; este sistema de lugares comunes se añade a los usos literales de la palabra que rigen las leyes sintácticas y semánticas, para formar un sistema de implicaciones, adecuando para una evocación más o menos fácil y libre (2001: 120-121).

El foco necesita de la oración completa para que nos otorgue el marco de sus posibilidades. Luego, la oración, como "marco", nos contextualiza las diversas recepciones que tengamos de la palabra focal: nos brinda trayectoria del impulso que ofrece la sola palabra metafórica.

$\mathrm{Al}$ volver un poco sobre la anterior cita, el foco "lobo" remitirá a las diversas manifestaciones que cada uno de los lectores posea del depredador. Según haya sido la experiencia con el término, la gama de significaciones pondrá en alerta las características que puedan adjudicarse a esta palabra metafórica. El "marco", la oración donde la palabra metafórica se mueve, otorga los límites para que todas aquellas atribuciones que se aplicaron al foco no transgredan el rumbo. El marco contiene la vorágine interpretativa. Empero, la contextualización de la palabra, es decir, del foco, no solamente emerge del bagaje cultural, estereotípico y referencial de la palabra. Sobreviene otro, uno que en rubros refigurativos es el que da vida a la imagen metafórica: la experiencia personal obtenida con la palabra es lo que también mueve la propia recreación de la metáfora. La interiorización de la metáfora es lo que da sentido a la interpretación que anida dentro de la lectura. De esta manera, la metáfora no solamente es el constructo, el ordenar las palabras para crear nuevas significaciones, sino también las emociones que surgen de dichas significaciones. Ricœur menciona un término en analogía con lo anterior: "Con el nombre de mood se introduce un factor extralingüístico que, aunque no hay que tratarlo psicológicamente, es el indicio o síntoma de una manera de ser" (2001: 303). Así, la metáfora se complementa con sus 
constructos semánticos y sensoriales. Con respecto a la semántica, el propio Ricœur dice: "la semántica se ha definido como ciencia de la significación de las palabras y de sus cambios de significación. El pacto entre la semántica y la palabra es tan fuerte que nadie sueña con colocar la metáfora en otro marco que el de los cambios de sentido aplicados a las palabras" (2001: 139). Así, podemos ayudarnos de la semántica para lograr aproximarnos a la propuesta metafórica (Ricœur también menciona los principios de "selección y plenitud", que se revisarán más adelante).

La metáfora es una exploración, es un viaje a través del reconocimiento, del reencuentro y del descubrimiento de nuevos significados:

La metáfora es entonces un acontecimiento semántico que se produce en la intersección de varios campos semánticos. Esta construcción es el medio por el que todas las palabras tomadas en su conjunto reciben sentido. Entonces, y solamente entonces, la torsión metafórica es a la vez un acontecimiento y una significación, un acontecimiento significante, una significación emergente creada por el lenguaje (Ricœur 2001: 134).

Su movilidad la mantiene viva. Trasladarse con ella significa aceptar su armonía vertiginosa, empatizar con esta "significación emergente creada por el lenguaje". En este flujo donde nos imbuimos, podemos mantener la concordia y la armonía de su impresión, de su emoción. En esta exploración se manifiestan dos fuerzas en sincronía. La oración metafórica nos lleva tanto a lo centrífugo como a lo centrípeto. Por un lado, la metáfora (como lectura), huye de su centro (el sentido original) hacia el plano equívoco, esta fuerza de huida del sentido genera confusión y abandono. Confusión, porque no genera diálogo o reflexión, se queda en la neblina y desorienta; incluso, hay ocasiones en que queda entre el texto y la lectura, pues existen ciertas oraciones metafóricas que son incomprensibles para el receptor y que bordean la incomprensión. La acción catártica se compromete, la pulsión anida en lo efímero. Sirva de ejemplo la siguiente metáfora: "Las libélulas celestiales son risas infinitas". Es posible apreciar cierto efecto poético; no obstante, el plano del insecto adjetivado y el gesto con el adjetivo, no producen un diálogo más allá de la sonoridad y las palabras ordenadas. No existe un reconocimiento, sino un efecto discordante de quien enuncia y quien acoge la intención, cualquiera que esta sea. Al no existir distinción entre lo escrito y lo leído, lo discordante eclipsa el diálogo literario. Impera luego un monó- 
logo y esto empuja al abandono de un único sentido. Abandono, porque lo literario no es solo la voz del autor o del lector; es precisamente un diálogo y una complicidad para dar origen a la actividad refigurativa; lo anterior, según Paul Ricœur (2009: 882), es el fundamento y el porqué de la literatura. Abandono en la creación, no solamente por parte del escritor, quien aísla su escritura en aras de sonoridad y policromía; sino del lector como figura recreadora de la imagen, sin acompañarse de la anterior faceta y sin proyectar un acompañamiento en su pensamiento literario. Autor y lector se abandonan en un lenguaje unívoco que se dispara al equívoco; existe trayectoria, pero no dirección. Existe distanciamiento del efecto metafórico cuando se crea una vorágine de posibilidades, no asentamos ni entendemos su fuerza: somos espectadores de un fenómeno incomprensible, bello por creación, indescifrable por discordante.

¿Qué sucede entonces con la metáfora? ¿Por qué pareciera escurrirse? Porque de ella no deseamos el concepto o la referencia, sino que nos ayude a evocar pensamientos, sentimientos y nos brinde una transfiguración del mundo: "Rehacer la realidad y, más precisamente, en el marco de la ficción narrativa, la realidad práctica, ya que el texto aspira intencionalmente a un horizonte de realidad nueva que hemos llamado mundo. Este mundo del texto interviene en el mundo de la acción para darle nuevas formas o, si se quiere, para transfigurarlo" (Ricœur 2010: 26).

Si dentro de la metáfora buscamos esta actividad, debemos comprenderla y esto se logra siempre a través de un diálogo. Recibirla con lo sensorial, con nuestro juicio y retornar con comprensión; co-creamos la obra de arte literaria.

Por ello se necesita esta fuerza centrípeta que posee la metáfora. Lo centrípeto ancla, posee una fuerza móvil y viaja junto con cierta referencia del sentido original; pero se necesita de esta tensión, de esta fuerza que jala hacia la posibilidad interpretativa para que se cumpla la razón de la metáfora. Esta fuerza, que pareciera escapar de su origen, da trazos para comprender su estado de movimiento; brinda un rastro que auxilia a componer la posibilidad del lenguaje. El anclaje produce empatía hacia el otro, hacia el que nos libera a través de su convivencia, de sus afecciones y discernimientos. Esta fuerza que no nos expulsa del camino de la empatía o de la comprensión, sino, por lo contrario, evita que nos proyectemos sin rumbo y que compartamos su dinamismo: nos ofrece una complicidad más que abandono y nos mantiene en el sendero de la refiguración. 
¿Qué sucede con la liberación lectora? Sin deseos o intenciones de una postura conservadora o limitante, esta liberación, que se da por medio de la comprensión de la metáfora, no surge como fuerza transgresora, sino como una libertad que se origina de acuerdo con el diálogo entre pares y esto es una libertad que se gana, fortalece y que conlleva a una catarsis más humanista.

La acción metafórica logra refigurar lo que no se encuentra dentro de este mundo referencial, y se encuentra trasladándose dentro de la comprensión. No podemos entenderla por completo porque aniquilaríamos el espacio íntimo y artístico para el cual fue engendrada; se tiene que interpretar para que nos proyecte hacia la comprensión de su posibilidad. Si, por un lado, lo centrípeto nos jala hacia la referencia, lo centrífugo nos defiende con lo equívoco. Son necesarias las dos fuerzas para crear un nuevo discurso que participe entre texto y lector y que nos dé el movimiento necesario para comprender la intencionalidad literaria: "de proyectar y de revelar un mundo" (Ricœur 2001: 127).

En esta revelación, la metáfora redescubre el mundo y abre horizontes. Su acción se centra en cómo deberían haber sido las significaciones, y cómo mostramos lo sensorial: "En otras palabras, el poder de la metáfora consistiría en destruir una categorización anterior, para establecer nuevas fronteras lógicas sobre las ruinas de las precedentes" (Ricœur 2001: 264). La oración metafórica brinda la oportunidad de viajar entre significaciones y emociones. El mundo estático y predecible nos opaca; una realidad con forma definida nos colapsa categóricamente. Tomar la base significativa, transformarla y recrearla junto con un halo de sentimientos a través de un reordenamiento estético nos libera y nos devuelve una reafirmación de nuestro estado humano: "No podemos decir cómo es la realidad sino cómo se nos presenta" (Turbayne, citado en Ricœur 2001: 333), y junto con lo anterior encontramos confirmaciones, cuasi juicios, aprendizajes y formas de apreciación que complementan el curso de nuestro pensamiento:

Una metáfora memorable tiene fuerza para poner en relación cognoscitiva y emotiva dos dominios separados, al emplear un lenguaje directamente apropiado a uno como lente para contemplar el otro: las implicaciones, sugerencias y valores sustentantes entrelazados con el uso literal de la expresión metafórica nos permiten ver un nuevo tema de una forma nueva (Black 1966: 232). 
La metáfora se crea cuando el lenguaje referencial no logra abarcar la magnitud de lo que vivimos y sentimos, entonces nace esta figura y nos ayuda a comprendernos. La facultad más significativa de la metáfora es el poder de proyectarnos a lo que vive dentro y fuera de nosotros, de identificarnos y comprendernos, elaborando una arquitectura con un nuevo sentido:

Partamos de que el sentido de un enunciado metafórico se suscita por el fracaso de la interpretación literal del enunciado; para una interpretación literal, el sentido se destruye a sí mismo. Pero esta autodestrucción del sentido condiciona a su vez un desmoronamiento de la referencia primaria. Toda la estrategia del discurso poético se juega en este punto: tiende a obtener la abolición de la referencia por la autodestrucción del sentido de los enunciados metafóricos, autodestrucción que se hace manifiesta por una interpretación literal imposible. Pero esta es solo la primera fase o, más bien, la contrapartida negativa de una estrategia positiva; la autodestrucción del sentido, por la acción de la impertinencia semántica, es solo el reverso de una innovación de sentido desde el punto de vista de todo el enunciado, obtenida por la "distorsión" del sentido literal de las palabras. Precisamente esta innovación de sentido constituye la metáfora viva (Ricœur 2001: 303-304).

La innovación de sentido despliega una nueva concepción para quien participa de la acción metafórica. Es una nueva visión liberada de su propio contexto. Podemos empatizar y complementarnos a través de la metáfora por medio de atributos e interiorizaciones, tanto del texto como de nosotros mismos. Aprehendemos la metáfora: con el pensamiento, con lo sensorial; en el torbellino de imágenes logramos percepciones que nos otorgan lo suficiente para reconocernos y comprendernos.

¿Cómo podemos lograr aproximaciones a través de la metáfora si esta nos significará según nuestra experiencia personal? ¿Qué pasa con la idea del autor, del texto mismo? Es importante recalcar que buscamos una mediación entre lo que nos ofrece el texto y lo que nosotros proyectamos. Nos alejamos así de interpretaciones y recepciones equivocistas y nos dirigimos hacia una aproximación con equilibrio, aunque apuntemos a lo subjetivo. El fenómeno literario busca empatía y dinamismo, más que intropatía y quietismo. Es importante mencionar lo que el hermeneuta francés puntualiza en su libro Del texto a la acción, donde remarca el papel de la interpretación como un agente mediador y no radical 
Tanto en mi análisis del relato como en los de la metáfora, lucho en dos frentes: por una parte, rechazo el irracionalismo de la comprensión inmediata, concebida como una extensión al terreno de los textos de la intropatía mediante la cual un sujeto se introduce en una conciencia extraña en la situación del cara a cara íntimo. Esta extensión indebida alimenta la ilusión romántica de un vínculo inmediato de congenialidad entre las dos subjetividades presentes en la obra, la del autor y la del lector. Pero rechazo con idéntica fuerza un racionalismo de la explicación que extendería al texto al análisis estructural de los sistemas de signos característicos no del discurso sino de la lengua. Esta extensión igualmente indebida engendra la ilusión positivista de una objetividad textual cerrada en sí misma e independiente de la subjetividad del autor y del lector. A estas dos actitudes unilaterales, he opuesto la dialéctica de la comprensión y la explicación (Ricœur 2010: 34-35).

Paul Ricœur sugiere dos principios a seguir si deseamos obtener "sentido" de la manifestación metafórica. El primero es "Un principio de conveniencia o de congruencia: se trata de decidir qué connotación conviene (can fit) al sujeto, entre las connotaciones del modificador. Este primer principio es más bien de selección” (2001: 131); el segundo principio actúa sobre el anterior: "es un principio de plenitud: todas las connotaciones que pueden 'ir con' el contexto deben atribuirse al poema” (2001: 131). De esta manera, en nuestro intento de perseguir sentido y dirección, el ejercicio va entre las significaciones que son internas, propias del texto y que comulgan con el contexto del escrito (como fuerza centrípeta); a la vez que nos confiere y nos permite producir significaciones externas al movimiento del texto, innovaciones semánticas (fuerza centrífuga). Este trabajo interpretativo nos confiere un autoconocimiento:

Comprenderse cara a cara a un mundo, es permitir que la obra y su mundo ensanchen el horizonte de la comprensión que yo hago de mí mismo. La interpretación es el proceso por el cual el descubrimiento de nuevos modos de ser da al sujeto una nueva capacidad de conocerse a sí mismo, el lector se ve agrandado en su capacidad de proyectarse a sí mismo al recibir un nuevo modo de ser del texto (Ricœur 2012: 85).

Tal es el poder de transfiguración de la metáfora. Al adentrarnos a su mundo y comprenderlo, cumplimos cabalmente con la premisa de metáforas auténticas que son acontecimiento y sentido: metáforas vivas. 


\section{Símbolo}

El concepto de símbolo se tomará, para este análisis, según el que utiliza Paul Ricœur en El conflicto de las interpretaciones: "llamo símbolo a toda estructura de significación donde un sentido directo, primario y literal designa por añadidura otro sentido indirecto, secundario y figurado, que solo puede ser aprehendido a través del primero" (2003: 17). El hermeneuta francés divide en tres campos la investigación que aborda al símbolo: el psicoanálisis, la poética y la historia de las religiones. Por razones obvias a la pertinencia del presente trabajo, se tomará el campo de la poética donde dice:

Si entendemos este término en un sentido amplio, entiende a los símbolos como imágenes privilegiadas de un poema, o como aquellas imágenes que predominan en la obra de un autor o una escuela literaria, o las figuras recurrentes dentro de las cuales una cultura entera se reconoce a sí misma, o aún las grandes imágenes arquetípicas que la humanidad en general exalta, ignorando las diferencias culturales (Ricœur 2006: 66).

La trayectoria del símbolo dentro de la obra literaria viaja como dentro de una red. No obstante, la red no inmoviliza, sino que en su entramado nos da rutas para construir la refiguración lectora. En el cara a cara, en la relación texto-lector, el valor del sentido se incrementa exponencialmente a causa de la refiguración. Poseemos una joya en bruto que vamos puliendo a través de la contextualización literaria y de las relaciones que entablamos con el símbolo: "la complejidad de los valores simbólicos es tal que se precisa del trabajo mancomunado de varias disciplinas que puedan esclarecer las relaciones inmanentes e intertextuales de los elementos que convergen en el símbolo, así, por ejemplo, el mito, la religión, la poesía, la narrativa, etc.” (Prada 1998: 8).

Esta dinámica se construye tanto en la lectura como en las reflexiones que surgen gracias al texto. La literatura nos da en qué pensar, nos abocamos dentro de ella y la conformamos en nuestro contexto. Por ello, y debido a este movimiento, sugerimos valorar el símbolo a través de las intertextualidades que generamos a partir de nuestra experiencia, junto con su peregrinar dentro de la obra literaria. Este viaje a través de las significaciones nutre la propiedad simbólica y recreacional. Al momento de hacer la recepción del texto por medio de construcciones subjetivas, el discurso resultaría volátil, sin mensaje claro para quienes lo buscaran: su abordaje requiere de la base 
referencial que lo soporta. Una representación con base en objetividades destruye simplemente el porqué de la representación simbólica. Las interpretaciones que demos del símbolo son contextualizantes; complementamos nuestros acercamientos a lo literario con lo referente. Así, el desglosamiento y la recreación se nutren y revitalizan entre las relaciones y los lazos de texto a texto, por medio de autor a lector. Símbolo es análogo a metáfora, en cuanto al excedente de sentido, y, dentro de la función del texto, se complementan. Si bien la metáfora participa mayormente en el excedente de sentido, dentro de ella buscamos su referente; el símbolo muestra su referente como puerta hacia lo equívoco. El símbolo es la guía, es lo centrípeto; la metáfora es la velocidad, lo centrífugo dentro de la voz literaria.

Renato Prada Oropeza menciona algo que atañe directamente a esta investigación en Los sentidos del símbolo II, y que nos da pie para añadir otra perspectiva sobre el transcurso interpretativo del símbolo: "el símbolo se instaura como portador de varias significaciones o, mejor, susceptible de varias interpretaciones. El símbolo del discurso artístico se interpreta, es polisémico: puede 'soportar' más de una interpretación, lectura, siendo cada una de ellas legítima si es coherente con sus principios” (1990: 54).

El desarrollo refigurativo que hacemos del símbolo parte desde cómo se nos presenta dentro de la obra literaria, tanto de su participación fija como activa. Esto es, como mero sustantivo cargado de su propia significación referencial, como del sentido subjetivo que le otorgamos. Por ello posee una cualidad polisémica, porque lo nutrimos de nuestra experiencia cultural.

Pero Prada Oropeza (1990) también menciona un aspecto de suma importancia sobre la interpretabilidad del símbolo en el "discurso artístico", y con esto logramos colocar la siguiente perspectiva.

La interpretación que hacemos del símbolo no solamente dependerá del lado referente o coherente del símbolo; tampoco de la intertextualidad y la carga subjetiva del excedente de sentido: la interpretación del símbolo obedece a las anteriores sumadas a una evolución que se gesta en el proceso de refiguración. Lo acompañamos y edificamos junto con su desenvolvimiento estético; mejor dicho, comenzamos a aprehenderlo según nuestro (nosotros lectores, junto con el símbolo) peregrinar dentro de la trama. Por ello es "discurso artístico", porque no se limita a lo que sabemos de él, sino que va enriqueciéndose al sumarse con lo que "no sabemos de él", pero que encontramos gracias a lo que experimentamos con él. Esta progresión simbólica lleva como guía la acción estética de la trama. Más allá de una delimitación 
que obstruye la refiguración, esta dinámica del símbolo, que elaboramos dentro del texto, es el sendero que nos lleva a la comprensión del texto literario y más aún nos permite:

Que la obra y su mundo ensanchen el horizonte de la comprensión que yo hago de mí mismo. Lejos de decir que un sujeto domina ya su propia manera de ser en el mundo y la proyecta como el a priori de su lectura diré que la interpretación es el proceso por el cual el descubrimiento de nuevos modos de ser -o si se refiere Wittgenstein a Heidegger, de nuevas 'formas de vida' [Lebensformen] — da al sujeto una nueva capacidad de conocerse a sí mismo. Si hay en alguna parte proyecto y proyección, es la referencia de la obra lo que es el proyecto de un mundo; en consecuencia, el lector se ve agrandado en su capacidad de proyectarse a sí mismo al recibir un nuevo modo de ser del texto mismo (Ricœur 2012: 85).

Mediante la progresión que realizamos junto con el símbolo dentro de la obra, logramos un cambio de horizonte, una formación: "Solo quien se ha formado es capaz de verse desde los otros y es capaz de poseer autodominio" (Luján 2007: 54).

El símbolo está constituido de una proporción entre lo objetivo y lo subjetivo: "está cargado de figuración, nos conduce al otro sentido, al que media, el que lleva de la mano, aun sin darnos cuenta, a lo escondido" (Beuchot 2007: 17). Existe dentro de esta progresión un balance que debemos cultivar, para que su interpretabilidad no sea del puro sujeto, porque el símbolo no nos mostraría toda su potencialidad. De otra forma no lograríamos la comprensión: "la comprensión no puede ser disociada de su devenir; ni el saber puede estar disociado del camino de la conciencia con que es alcanzado. El método no puede estar disociado de los contenidos. En la 'formación del objeto' no es algo extrínseco, es apropiado y configura la conciencia del intérprete" (Luján 2007: 54-55).

Luego, si el camino hacia la interpretación del símbolo está en progresión, tal progresión no debe ser transgresora, de manera que el producto refigurado se pierda y sea inalcanzable; de igual manera, no podemos apresar el símbolo e imponer condiciones, debido a que este es cultural. Nuestra aproximación debe lograr un equilibrio entre aquello que históricamente nos han heredado y nuestra refiguración construida. ¿Cómo podemos lograr una adecuada interpretación del símbolo dentro del texto literario? Para que la progresión no nos rebase, o no la rebasemos, es necesario seguir un método 
que nos guíe a través del camino hacia la comprensión de este. Paul Ricœur y Mauricio Beuchot concuerdan en que existe un método que nos apoya para generar la comprensión del símbolo. Hay que puntualizar que ambos hermeneutas especifican que no existe un camino propiamente cimentado para descifrar en su complejidad el símbolo; empero, sí existen modos de acercarnos a él: "Si no hay reglas para hacer conjeturas válidas, hay métodos para hacer válidas las conjeturas que hacemos" (Ricœur 2006: 88).

En Tiempo y Narración III, Ricœur menciona que el acto de leer debe generar una expansión y elaborar: "Un proyecto más ambicioso, el de constituir una hermenéutica literaria. Debe asumir la triple tarea, evocada anteriormente, de comprender (subtilitas intelligendi), de explicar (subtilitas interpretandi) y de aplicar (subtilitas applicandi)" (2009: 892). Esta tarea se desarrolla en el análisis del símbolo, ya que el símbolo no se presenta diáfano: "El símbolo permanece opaco, no transparente, puesto que se da por medio de una analogía, sobre la base de un significado literal, que a la vez le confiere raíces concretas y un peso material, una opacidad" (Ricœur 2003: 289). Asimismo, Beuchot (2009) refiere que al momento de interpretar se debe guardar un equilibrio entre los extremos interpretativos a los cuales nombra, equívoco y unívoco, siendo el primero la validación de cualquier tipo de traslación del texto; y el segundo, una sola comprensión existente del mismo. Para Beuchot, lo idóneo es lograr una proporción, una analogía, entre ambas hermenéuticas para lograr un mejor acercamiento. El teórico mexicano desarrolla la labor del método anteriormente sugerido de la siguiente manera:

El método de la hermenéutica en tres pasos que son tres modos de sutileza: (i) la subtilitas intelligendi - y que nosotros quisiéramos llamar subtilitas implicandi-, (ii) la subtilitas explicandi y (iii) la subtilitas applicandi. En ese primer paso se va al significado textual o intratextual e incluso al intertextual. Después vendrá la subtilitas explicandi correspondiendo a la semántica. Y finalmente se va a la subtilitas applicandi, correspondiente a la pragmática (lo más propiamente hermenéutico), en la que se toma en cuenta la intencionalidad del hablante, escritor o autor del texto y se lo acaba de insertar en su contexto histórico-cultural. Esto coincide además con tres tipos de verdad que se darían en el texto: una verdad sintáctica, como pura coherencia, que puede ser tanto intratextual (interior al texto) como intertextual (con otros textos relacionados); una verdad semántica, como correspondencia con la realidad (presente o pasada) o con algún mundo posible (futuro o imaginario) a que el texto alude, y una verdad pragmática, como convención 
entre los intérpretes (e incluso con el autor) acerca de lo que se ha argumentado y persuadido de la interpretación, a pesar de que contenga elementos extratextuales (subjetivos o colectivos) (2009: 20-21).

Ambos hermeneutas convienen en que la subtilitas es el método idóneo para acercarnos a la interpretación del texto y, por lo tanto, del símbolo. Hay que especificar que, en estos niveles de acercamiento, tomaremos las definiciones según lo recorrido por ambos autores tanto en su teoría, como en la presente investigación. Así, en el primer nivel que corresponde a la subtilitas implicandi, analizaremos las conexiones intertextuales e intratextuales que nos genera el símbolo. Al poner en relieve el símbolo, podremos comprenderlo mejor siguiendo lo expuesto tanto por Ricœur como por Beuchot. En la subtilitas explicandi nos valdremos de la semántica de la misma manera en que Ricœur la explica en La metáfora viva y en Tiempo y narración; dentro de subtilitas applicandi nos enfocaremos a lo expuesto por Beuchot en Tratado de Hermenéutica analógica, lo pragmático. El símbolo puede pasar a través de estos tres niveles de aproximación; sus dos caras, lo expuesto y lo oculto, se pondrán en perspectiva para que, finalmente, a través del método, podamos lograr la aproximación y la comprensión del símbolo dentro del texto literario.

\section{Ejercicio}

En esta tercera sección se aplicará la teoría revisada. El orden en cuanto a la interpretación de la metáfora será el siguiente: se tomarán en cuenta algunas de las significaciones internas que son propias del texto y que comulgan con el contexto del escrito; en segunda instancia se tomarán las significaciones externas, que alumbramos a partir de la lectura del texto; como tercer paso, se expondrán los resultados del análisis.

Tomamos el cuento "El prodigioso miligramo" del narrador mexicano Juan José Arreola. Este relato nos plantea la historia de una hormiga, la cual, "censurada por la sutileza de sus cargas y por sus frecuentes distracciones, encontró una mañana, al desviarse nuevamente del camino, un prodigioso miligramo" (2006: 99), cuyo peso y dimensiones eran ideales para alguien con sus condiciones. Las demás hormigas encuentran deleznable este comportamiento, así que la someten a juicio y la encarcelan. La hormiga no dormía por estar puliendo al miligramo y de día quedaba absorta ante él. Presa 
de su locura, la encuentran muerta un día al amanecer. Después del acaecimiento de la hormiga, otras hormigas comenzaron a ver lo "prodigioso del miligramo", llevaron ofrendas al cuerpo de su compañera muerta, hubo guardias especiales que resguardaron el miligramo. Toda la sociedad quedó rendida y lo veneraba; hasta en otros hormigueros comenzaron a rendirle pleitesía. Entonces sucedió lo esperable: "El hormiguero comenzó a llenarse de falsos miligramos" (2006: 103). Es en esta última oración donde centraremos el análisis.

¿En qué condición se encuentra el hormiguero y cómo estos otros "miligramos" modifican la realidad de sus habitantes? Arreola nos deja la tarea de completar su juego literario. Esta situación es adversa al hormiguero, pues su población ya tiene un orden natural establecido. No obstante, una hormiga en específico modifica sus patrones al llevar algo que no se concreta con precisión, pero sí tiene el poder suficiente para alterar este orden que han seguido por mucho tiempo. El miligramo comienza a fracturar el comportamiento de la hormiga "distraída", la torna errática y obsesiva. Al final: "el prodigioso miligramo brillaba en el suelo, como un diamante inflamado de luz propia. Cerca de él yacía la hormiga heroica, patas arriba, consumida y transparente" (Arreola 2006: 101). Este hecho asombra a toda la comunidad. El hormiguero comienza a volcarse en el miligramo y lo convierte en objeto de culto. La multitud se enajena con este objeto, y no tardan en aparecer hormigas que quieren imitar las actitudes de aquella primera y muchas confesaban haber encontrado miligramos, es por ello que, de pronto, se encuentran inmersos con "falsos miligramos".

Dentro del texto, el papel del miligramo va de lo mundano a lo sublime. En un principio carece de todo valor; incluso su descubridora muere en aislamiento. No es sino hasta después que adquiere un valor prodigioso e invaluable. La sociedad de hormigas colapsa, pues empiezan a "descubrir" otros miligramos parecidos, lo cual las exenta del trabajo y las labores propias. Su organización entonces declina.

Esta situación crítica que describe Arreola se asemeja al desorden ferroviario de "El guardagujas" (2006: 77-84), "la empresa” y sus habitantes. Dentro del país del guardagujas, la población sufre los embates de las "leyes" de una empresa que no tiene un buen servicio de trenes y que hace que todo habitante o quien cruce por el lugar caiga en el infortunio, en la pérdida de dirección. Entre más trenes, más caminos equívocos y falta de decisiones. Los habitantes y visitantes se entregan a la expectativa, a la suerte. 
Cosa similar ocurre con el hormiguero: el miligramo y los falsos miligramos rompen la naturaleza de su comportamiento y se entregan al deparo de un objeto que en primera instancia ignoran qué es, pero que envuelve la atmósfera y desgaja su comportamiento y el de aquellos que lo visiten. Su modus operandi se resquebraja. El ciclo natural se diluye y colapsa. Los falsos miligramos se multiplican, así como las desavenencias entre las hormigas. Esta situación recuerda el declive de la organización humana. Si el hormiguero cae ante objetos de adoración, la sociedad cae en sus propios cultos: "dinero", "formas de gobierno", "religión”. Nuestra sociedad está "distraída” y alienada tratando de seguir o conseguir miligramos.

Luego, "El hormiguero comenzó a llenarse de falsos miligramos" (Arreola 2006: 103), se plantea como la oración metafórica y como la reconstrucción del objeto de perdición, aquel que lleva a la ruina a las personas. Si lo tomamos como objeto de culto, los "falsos miligramos" serían los diferentes subordinados que solo son peores que el primero. Estos objetos de culto bien pueden representar las simulaciones, las políticas, las instituciones.

Sigue el turno de analizar "el miligramo" como símbolo, según lo establecido en el anterior apartado. ¿Existen vínculos simbólicos entre la obra arreolina para sustentar una crítica a la sociedad? En relatos como "Baby H. P.” (2006: 121) y "Anuncio" (2006: 123) el autor utiliza el símbolo como recurso primordial para exponer el absurdo en el que caen la ciencia y la tecnología; en Bestiario aparecen las actitudes execrables de la humanidad simbolizadas en los animales. Tanto en los primeros como en los segundos se distingue una mordaz crítica de la sociedad en conjunto. Juan José Arreola se apoya en el cultivo del símbolo y lo sabe desarrollar para que comulgue con la trama y se desprendan de él sus bastas interpretaciones.

Entonces, podemos comprender al miligramo como un objeto ínfimo y de aparente futilidad, levantarlo no representa mayor esfuerzo para una hormiga obrera, pues estas logran cargar hasta diez veces su propio peso y arrastrar otros cincuenta. Empero, este objeto, en apariencia ínfimo y en inicio banal, conlleva el infortunio convirtiéndose en indispensable y obsesivo para la colonia. Su influencia hace caer a las hormigas y lo desean tanto que comienzan a buscar el propio; menos radiante a los ojos ajenos, pero que cumple con la función utilitaria. Se cobijan bajo el influjo de falsos ídolos y se precipitan al vacío. El hormiguero cae.

La relación existente entre el "prodigioso miligramo", banalizado en primera instancia, y después convertido en objeto de culto, puede interpretarse 
como una metáfora de la corrupción que ha enfrentado la humanidad en su historia y sus sistemas de control, iniciados con "buena intención", pero que solo hizo que el hormiguero, nuestra sociedad, comenzara a llenarse de "falsos miligramos", entiéndase como cualesquiera representaciones de poder.

Dentro de "El prodigioso miligramo" de Juan José Arreola, encontramos también el desvarío y el carácter irracional de la humanidad (reflejados en las hormigas), volcada a un objeto que se sabe no tiene propiedad alguna, pero que su vehemencia les otorga la necesidad y después la creencia de que este objeto logre destacarlas y hacerlas diferentes a las demás, esta pertenencia otorga un derecho de poder con respecto al prójimo.

Como sociedad, ¿cuáles son nuestros falsos miligramos? Instituciones corrompidas, interpretaciones equívocas de cultos, ideas políticas basadas en provocaciones: construidos, brillantes y resplandecientes a costa de la población, la cual, inclusive puede morir por ellos y arrastrar a otros a su mismo destino. Dentro del texto, el autor nos expone el desplome de la sociedad, mayormente preocupada en su comodidad y fines propios, deja de hacer el bien común y se pierde la finalidad y fortaleza de todo individuo que es la propia sociedad.

\section{Balance}

La metáfora como una innovación redescriptiva y el símbolo como una figura construida mediante dos caras, la referente y la oculta, brindan y recrean al texto literario. Si la construcción de sentido de estas figuras las aparta, en el excedente de sentido se vuelven a unir. Ambas figuras poseen movimiento, lo centrífugo y lo centrípeto. Dentro del símbolo, encontramos que lo centrípeto nos recibe desde la primera lectura, y partimos de ahí a nuestro viaje a lo centrífugo. La metáfora, a su vez, viene acompañada de lo centrífugo y debemos buscar el ancla que nos sujete para comprender su movimiento, para no dejarnos llevar por su intempestiva fuerza. Símbolo y metáfora transitan dentro de la obra literaria, se posicionan en la trama y nutren la refiguración que hacemos dentro del acto de leer. La interpretación que hacemos de ellos se da como progresión, es un enriquecimiento que elaboramos junto con la obra de arte literaria.

Dentro de las guías que nos dan Ricœur y Beuchot para adentrarnos a sus significados, encontramos que lo que propone el teórico francés es análogo a lo que Mauricio Beuchot nos expone en la subtilitas. Si para el análisis de 
la metáfora Ricœur nos sugiere valorar la metáfora según las connotaciones convenientes o congruentes (fit) como un "principio de selección", esto es proporcional a lo que el filósofo mexicano esboza en su método y que refiere a los enlaces intertextuales e intratextuales; aquí es identificar las posibles familiaridades que se dan entre texto y texto. Después, ambos autores proponen la semántica como recurso natural de seguimiento: "La semántica se ha definido como ciencia de la significación de las palabras y de sus cambios de significación. El pacto entre semántica y palabra es tan fuerte que nadie sueña con colocar la metáfora en otro marco que el de los cambios de sentido aplicados a las palabras" (Ricœur 2001: 139). Esta guía nos otorga un panorama adecuado para llevarnos al siguiente paso, de un horizonte explicativo, a otro comprensivo. Por consecuencia, podemos hacer nuestra esta refiguración y se compartirán los horizontes, el del texto y el del lector, para dar cabida a uno nuevo con fundamentos en la comprensión del texto ya interpretado (subtilitas applicandi).

\section{Bibliografía}

Arreola, Juan José (2006). "El prodigioso miligramo", en Confabulario definitivo, ed. Carmen de Mora. Madrid, Editorial Cátedra: 99-106.

Beuchoт, Mauricio (2007). Hermenéutica analógica, símbolo, mito y filosofía. México, Universidad Nacional Autónoma de México.

Beuchot, Mauricio (2009). Tratado de hermenéutica analógica: hacia un nuevo modelo de interpretación. México, Universidad Nacional Autónoma de México.

BLACK, Max (1966). Modelos y metáforas. Madrid, Editorial Tecnos.

Domingo Moratalla, Tomás (2003). "La hermenéutica de la metáfora: de Ortega a Ricœur", Espéculo, Revista de Estudios Literarios, <https://pendientedemigracion. ucm.es/info/especulo/numero24/ortega.html>, consultado por última vez el 1 de junio de 2017.

LujÁN SAlAZAR, Enrique (comp.) (2007). "Hermenéutica, analogía e historicidad", De la analogía al símbolo: Vertientes de la hermenéutica, pról. Mauricio Beuchot. México, Universidad Autónoma de Aguascalientes.

Prada Oropeza, Renato (1990). "El símbolo literario y su interpretación psicoanalítica”, <http://cdigital.uv.mx/handle/123456789/6428>, consultado por última vez el 18 de junio de 2017.

Prada Oropeza, Renato (1998). Los sentidos del símbolo II. Puebla, Universidad Iberoamericana.

Ricceur, Paul (2001). La metáfora viva, trad. Agustín Neira. Madrid, Editorial Trotta. Riceur, Paul (2003). El conflicto de las interpretaciones: Ensayos de hermenéutica, trad. Alejandrina Falcón, rev. Pablo Corona. México, Fondo de Cultura Económica. 
Ricceur, Paul (2006). Teoría de la interpretación: Discurso y excedente de sentido. México, Editorial Siglo XXI.

Ricceur, Paul (2009). Tiempo y narración III, trad. Agustín Neira. México, Editorial Siglo XXI.

Riceur, Paul (2010). Del texto a la acción: Ensayos de hermenéutica II, trad. Pablo Corona. México, Fondo de Cultura Económica.

Ricceur, Paul (2012). Escritos y conferencias 2, trad. Adolfo Castañón. México, Editorial Siglo XXI.

\section{Iram Isaí Evangelista Ávila}

Doctor en Humanidades-Literatura por parte de la Universidad Autónoma Metropolitana. Docente-investigador de tiempo completo en la Facultad de Filosofía y Letras de la Universidad Autónoma de Chihuahua. Miembro del Sistema Nacional de Investigadores nivel I. Líder del Cuerpo Académico "Estudios Humanísticos de la Cultura”. Imparte cátedra en Licenciatura en Letras Españolas, Maestría en Investigación Humanística y Doctorado en Educación, Artes y Humanidades. Su trabajo se centra en teoría y crítica literaria aplicada a la literatura hispanoamericana. Tiene publicados tres libros: Juan José Arreola, su cuento a través de la analogía, Ensayar al confabulador y Hermenéutica de la autoficción, artículos y capítulos de libro en diversas publicaciones de prestigio nacional e internacional; ha sido ponente en congresos nacionales e internacionales de literatura contemporánea. 